\title{
Indigenous Knowledge Practices and Community Adaptation to Coastal Flooding in Ada East District of Ghana
}

\author{
Seth Cudjoe ${ }^{1, *}$, Samuel Kwabla Alorvor ${ }^{2}$ \\ ${ }^{1}$ Department of Geography, Environment and Energy Studies, University of Johannesburg, Johannesburg, South Africa \\ ${ }^{2}$ Department of Development and Environmental Studies, Wisconsin International University College, Accra, Ghana
}

Email address:

cudjoe@andrews.edu (S. Cudjoe), samuelalorvor@gmail.com (S. K. Alorvor)

${ }^{*}$ Corresponding author

\section{To cite this article:}

Seth Cudjoe and Samuel Kwabla Alorvor. Indigenous Knowledge Practices and Community Adaptation to Coastal Flooding in Ada East District of Ghana. Hydrology. Vol. 9, No. 1, 2021, pp. 13-20. doi: 10.11648/j.hyd.20210901.12

Received: October 30, 2020, 2020; Accepted: November 12, 2020; Published: March 26, 2020

\begin{abstract}
The role of indigenous knowledge in flood risk reduction and management has not received the attention it deserves in Ghana as little is known about how coastal communities use indigenous knowledge to deal with coastal flooding. The study sought to find out how indigenous knowledge is used as an adaptation response to coastal flooding in Totope, a coastal community in Ada East District of Ghana, which is affected by coastal flooding. A total of fifty-three (53) household heads and seven (7) key informants were purposively selected for questionnaire administration and focus group discussions. The study revealed that storm surges was the cause of coastal flooding in the study community. The study found that the people of Totope have rich indigenous knowledge which they use to deal with the coastal flooding. The people used sandbags to serve as barriers preventing flood water from getting into their compounds and rooms; they raised the foundations of their buildings; they reinforced their windows using trampoline to prevent floodwaters from entering their rooms; they created platforms in their rooms on which they pack their valuables when floodwaters breach the barriers created; they created pathways for floodwater to pass; and varied their livelihoods and the crops they produce as a response to flooding. The study further revealed that there was an increase in the intensity of storm surges in recent times in the community. The study concluded that a lasting solution to the coastal flooding menace in the community was the construction of a sea defense systems.
\end{abstract}

Keywords: Coastal Flooding, Storm Surges, Indigenous Knowledge, Adaptation, Adaptive Capacity, Sea Level Rise (SLR)

\section{Introduction}

The $21^{\text {st }}$ century is witnessing a sharp rise in hazards particularly flooding in low lying coastal communities due to sea level rise $[35,48]$. Sea level rise is induced by the rise in global temperature which is caused by increasing anthropogenic activities [24, 25]. The rise in global temperature leads to the melting of ice sheets and glaciers, and thermal expansion of the sea, and leading to sea level rise with the end result being coastal flooding [23, 24, 31, 45]. The rate of coastal flooding has over the years risen from two per year to more than six per year $[15,24,33,43,44,46]$.

With global mean sea level expected to rise on the order of $0.3-1.0 \mathrm{~m}$ by 2100 , so will coastal flooding and its associated impacts exacerbate $[13,16,30,38,50]$. The impacts of coastal flooding include: the permanent submergence of coastlands; coastal erosion; loss and change of coastal ecosystems; salinization of soils, ground and surface water; loss of livelihoods, and the destruction of properties $[14,15,24,31$, 43-46].

The enormity of the challenges posed by coastal flooding has drawn the attention of local and international researchers as they seek to find best suited mitigation and adaptation strategies for communities in the face of rising sea levels $[11,13,22,28,32$, $47,49]$. Over the years, several strategies have been adopted to mitigate and respond to coastal flooding [12, 17, 29]. The strategies have been grouped into scientific and traditional strategies $[18,20,37]$. The scientific strategy is highly technical and often beyond the means of local communities as it requires huge financial investments if it is to be adopted [40, 41]. In this 
regard, local communities have to depend on the central government, state agencies or international development partners for the adoption of this strategy in response to flooding in their communities. The traditional strategy for coastal flood management is based on indigenous knowledge developed over time [20,37]. This strategy allows local communities to build on their experiences and strength to develop appropriate responses to coastal flooding [21]. Indigenous knowledge for coastal flood management is acquired through the practice of coping mechanisms [36]. This knowledge is believed to be revealed through intuitions, dreams or visions [3]. Development practitioners have argued that indigenous knowledge is very important in planning for community development [34] and that developmental strategies cannot be completely successful without the implementation of indigenous knowledge [42]. Indigenous knowledge thus provides communities with ideas for tackling local problems and helps in their developmental processes [26].

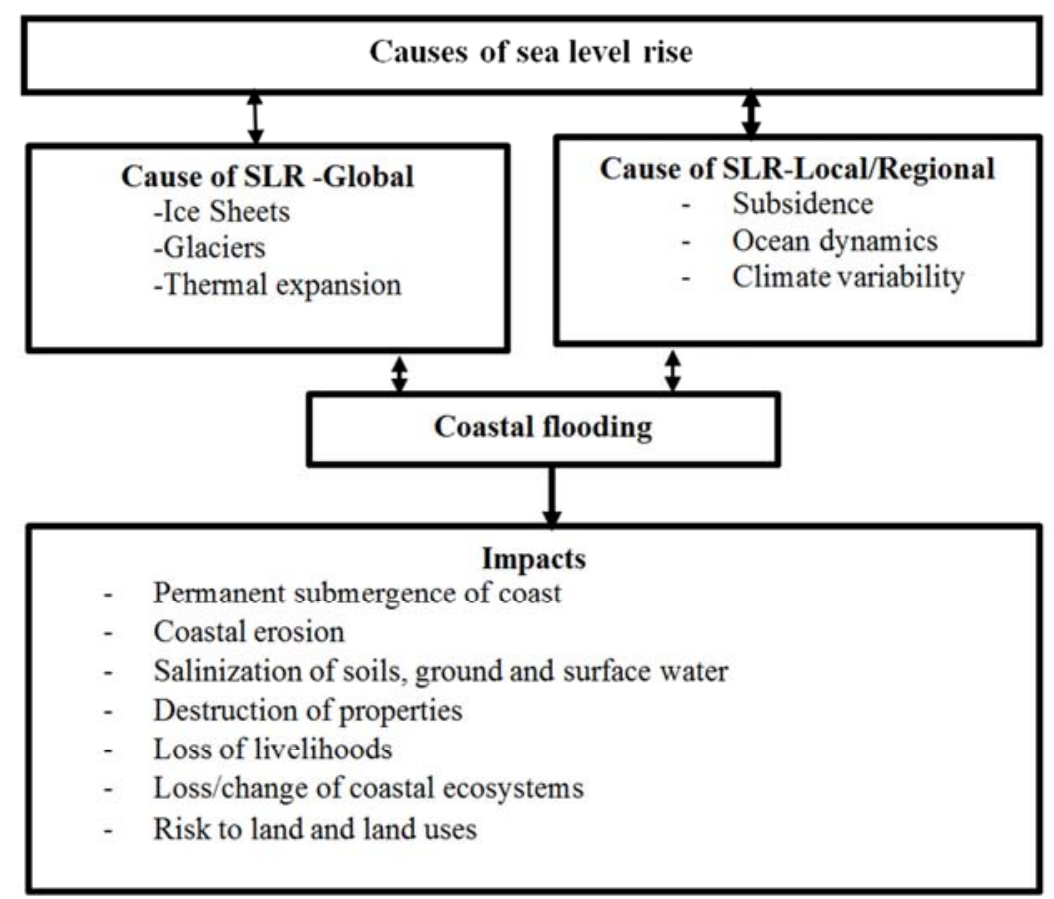

Source: IPCC Special Report on the Ocean and Cryosphere in a Changing Climate

Figure 1. Causes of sea level rise (SLR), coastal flooding and associated impacts.

\subsection{Statement of Problem}

The Ada East District, which forms part of the communities along the south-east coast of Ghana is not spared the effects of sea level rise as communities in the district are pounded by sea waves due to the districts' lowlying elevation (60 meters above sea level). It is estimated that between 6-8meters of the district's coastal land is lost to the sea every year and the coastline of the district is gradually disappearing $(1,8,9)$. Government in an attempt to deal with the problem adopted the use of scientific strategies including the building of sea defense walls and groynes. Unfortunately the lack of financial resources has stalled the completion of the scientific strategies as only $25 \%$ of the $24.7 \mathrm{~km}$ sea defense wall started in 2010 along the coastline of the Ada East district has been completed. This challenge has exposed many of the coastal communities in the district to the impacts of coastal floods. In the face of the financial challenge and with help from government far from coming, the question that remains to be asked is how communities in the district use indigenous knowledge as a coping strategy to flooding. The study therefore sought to find out how indigenous knowledge have been used by households in Totope as an adaptation strategy to combat coastal flooding in their community.

\subsection{Objectives}

The study was guided by the following objectives:

1. To investigate the flood experiences of households;

2. To identify the indigenous strategies adopted by households to deal with coastal flooding;

3 . To expose the challenges of using indigenous strategies as an adaptation response to the coastal flooding.

\section{Methodology}

The qualitative research approach was adopted for the study. The decision to use the qualitative research approach was influenced by the research objectives as the approach provided an avenue for the researcher to ask open ended questions that helped obtain in-depth, rich and descriptive information on the subject matter being investigated. The purposive sampling technique was used to select Totope as the study area based on the fact that it is a coastal community in the Ada East district of Ghana predisposed to the impacts 
of coastal flooding. The purposive sampling technique was also used to select the chief fisherman, chief farmer, head of salt winners and four (4) elders of Totope for a focus group discussion on the subject matter being investigated. The convenience sampling technique was adopted to select fiftythree (53) household heads out of a total of one hundred and fifty (159) household heads for the purposes of questionnaire administration. Data for the study was collected using both questionnaires and focus group discussions.

\section{Findings}

This section presents the analyses of data from the field work that sought to find out how indigenous knowledge have been used as an adaptation strategy to coastal flooding in Totope, a coastal community in the Ada East district of Ghana.

\subsection{Profile of Study Area}

The Ada East District is one of the sixteen (16) districts in the Greater Accra Region of Ghana. Its capital is Ada Foah. The district has a total land area of $289.783 \mathrm{~km}^{2}$, a total of 15 , 631 households, and a total population of 71,671 [19]. The District was established in 2012 by Legislative Instrument (L. I) 2029, when it was carved out of the former Dangme East District. The District shares common boundaries with the Central Tongu District to the North, South Tongu District and Ada West to the East and West respectively. It is bounded to the south by the Gulf of Guinea, which stretches over 18 kilometers from Kewunor to Totope. It is also bounded by the Volta River South-Eastwards extending to the Gulf of Guinea southwards thereby forming an Estuary, about 2 kilometers away from the District capital, Ada-Foah. The District forms the central portions of the Accra plains and the district is a low plain with heights not exceeding 60 meters above sea level. The low lying nature of the district has exposed most of the communities in the district to the impacts of coastal flooding.

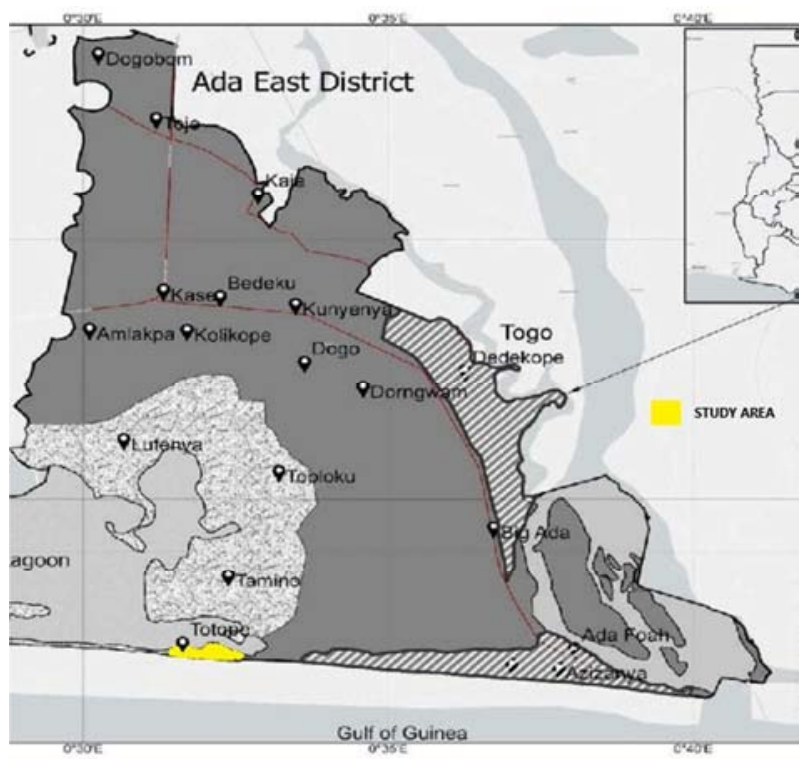

Figure 2. Ada East District Map.

\subsection{Occupation of Respondents}

The survey results as illustrated in Figure 3 disclosed that the people in the study area engaged in three economic activities, that is fishing, salt winning and farming. A total of $64 \%$ of the respondents engaged in fishing as a source of livelihood.

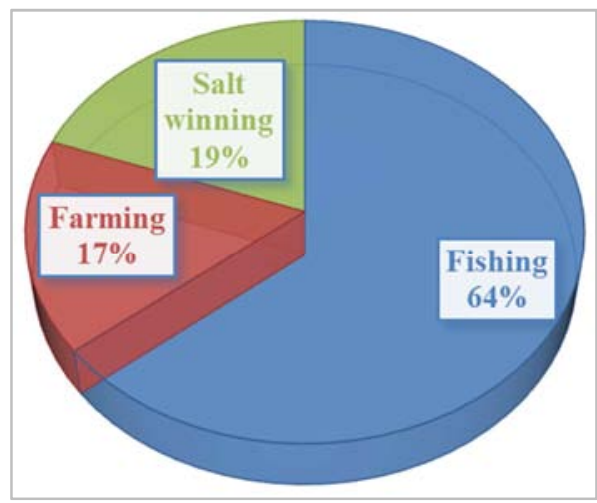

Figure 3. Occupation of respondents

Also, $17 \%$ of the respondents engaged in farming as a source of livelihood whilst $19 \%$ of the respondents engaged in salt winning in the Songhor lagoon as a source of livelihood. The result suggests that majority of the people in Totope are fishermen.

\subsection{Household Flooding Experience}

The survey results showed that $45 \%$ of the respondents have been exposed to flooding in the study community for more than 10 years. Also $30 \%$ of the respondents revealed that they have been exposed to flooding for between 610 years whilst $25 \%$ of the respondents stated that have been exposed to flooding between $2-5$ years.

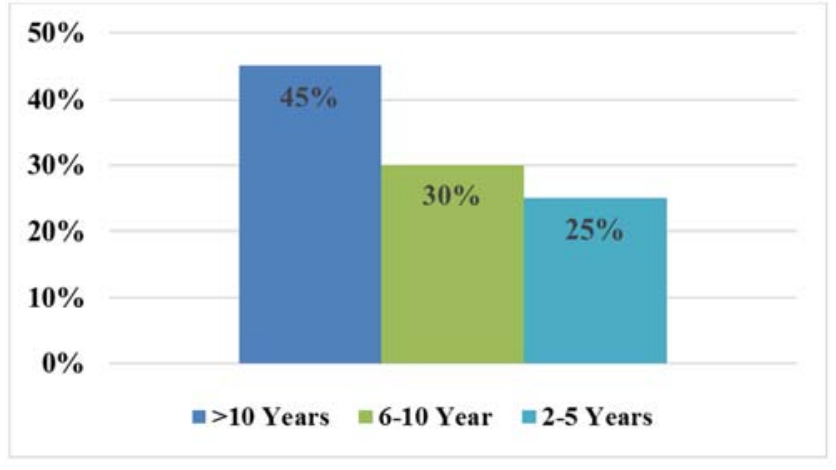

Figure 4. Flood experience of respondents.

All the 7 participants in the focused group discussion stated that they have been staying in the community for over 10years and that their flood experience worsened in the 2000's when waves became stronger. All the respondents in participated in the household questionnaire survey and focused group discussion stated that there are variations in household flood experience because some of the residents migrated from other communities to reside in Totope to 
engage in fishing and salt winning in the Songhor lagoon.

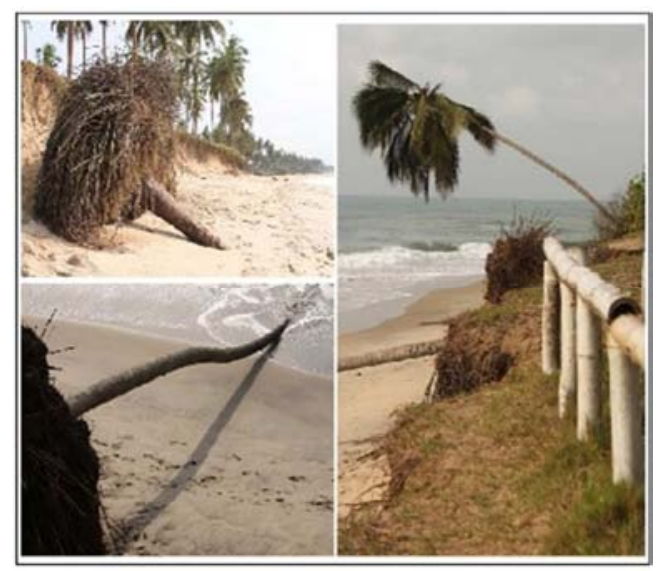

Figure 5. Eroded coastline in Ada, Ghana.

\subsection{Year of Latest Flood}

It emerged from survey results that $22.6 \%$ of respondents experienced the latest flood in 2018. A total of $13.2 \%$ of the respondents experienced their latest flood in 2017. The field result as illustrated in Table 2 suggest that not all households experience flood during periods of flooding as it is evident in the field result that out of the total of fifty-three (53) respondents, only twelve (12), representing $23 \%$, experienced flooding as at the time data was collected in May, 2018.

Table 1. Year of latest coastal flooding.

\begin{tabular}{ll}
\hline Year & Percentage (\%) \\
\hline 2010 & 1.9 \\
2011 & 1.9 \\
2012 & 7.5 \\
2013 & 9.4 \\
2014 & 13.2 \\
2015 & 7.5 \\
2016 & 22.6 \\
2017 & 13.2 \\
2018 & 22.6 \\
Total & 100 \\
\hline
\end{tabular}

The household result was reiterated by the 7 participants in the focused group discussion who maintained that not all households experience flood during the period of floods and that the number of households that experienced flood is dependent on the severity of the floods. They pointed out that the worst flood experience is mostly in August when the waves are strong.

\subsection{Causes of Coastal Flooding}

The study sought to find out from the respondents the causes of flooding in the community. The survey results as illustrated in Table 2, indicates that a total of $57 \%$ of the stated that the cause of flooding in the community was the result of storm surges. A total of $23 \%$ of the respondents attributed flooding in the community to heavy rains that battered the community during certain times of the year. Also $20 \%$ of the respondents attributed the cause of flooding in the community to the anger of the gods. The $20 \%$ of the respondents opined that flooding in the community was a divine retribution. A respondent quoted Ezekiel 13:13 to support his position that flooding in the community can be attributed to the anger of God.

Therefore this is what the Lord GOD says: 'In My wrath I will release a windstorm, and in my anger torrents of rain and hail will fall with destructive fury' (Ezekiel 13:13).

Table 2. Causes of Flooding.

\begin{tabular}{ll}
\hline Causes & Percentage \\
\hline Storm surges & 57.0 \\
Heavy rains & 23.0 \\
Act of gods & 20.0 \\
Total & 100 \\
\hline
\end{tabular}

The position of majority of the respondents on the causes of flooding is corroborated by Needham et al (2011), who attributed coastal flooding to storm surges as a result of persistent onshore winds, in conjunction with reduced air pressure which force water levels to rise and lead to flooding in low-lying coastal areas.

\subsection{Period and Duration of Floods}

All the respondents $(100 \%)$, unanimously agree that flooding occurs in the community in January-February and July-August each year. The respondents stated that floods lasted between 2-3 weeks in January-February and between 3-4 weeks in July-August. This position is corroborated by researchers at the National Oceanic and Atmospheric Administration (NOAA) who say that storm surges develop in late summer months (July-August in the Northern Hemisphere, January-February in the Southern Hemisphere), when the ocean waters are warmest.

\subsection{Indigenous Adaptation Strategies as a Response to Coastal Flooding}

\subsubsection{Factors Affecting Choice of Adaptation Strategy}

All the respondents $(100 \%)$, unanimously agreed that they undertook strategies to guard against the persistent flooding in the study community. As illustrated in Figure 6, respondents' choice of adaptation strategy was influenced by a myriad of factors.

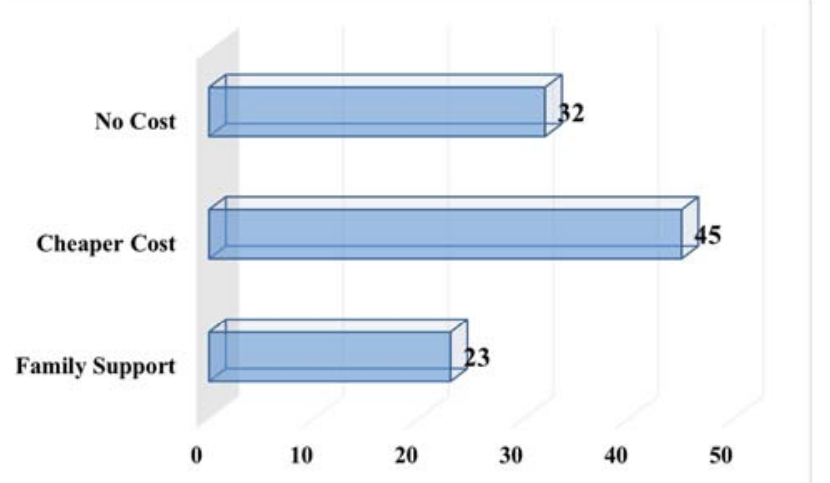

Figure 6. Factors influencing choice of adaptation. 
The survey results showed that $45 \%$ of the respondent stated that their choice of adaptation strategy was influenced by cheaper cost. Also, $23 \%$ of the respondents stated that their choice of adaptation strategy was influenced by the availability of family support to carry out the adaption strategy whilst $32 \%$ of the respondents stated that their choice of adaptation was influenced by the no cost associated with adopting the adaptation strategy.

\subsubsection{Source of Knowledge of Indigenous Adaptation Strategy}

Survey results suggest that respondent's sources of knowledge for their choice of adaptation strategy included family, friends, neighbours, social groups and elders. A total of $28 \%$ of the respondents opined that the source of knowledge for their adaptation strategy was obtained from elders in the community as the elders were seen a repository of knowledge to combat coastal flooding in the community. Also $21.7 \%$ and $22.8 \%$ of the respondents stated that the knowledge for their choice of adaptation strategy was obtained from neighbours and family members respectively. The result suggest that elders, family members and neighbours played an important role in passing down indigenous knowledge on adaptation from generation to generation.

The participants in the focus group discussion pointed out that the main mode of transmission of knowledge on adaptation strategies was verbal instruction from parents and elders and from the observation of parents and elders carry out the adaptation strategy. The findings is corroborated by Agrawal (1995) who posits that indigenous knowledge is passed down generations and gained from the knowledge of the environment which is revealed through intuitions, dreams or visions.

Table 3. Source of knowledge of choice adaptation.

\begin{tabular}{ll}
\hline Source of knowledge & Percentage \\
\hline Family & 22.8 \\
Friends & 8.5 \\
Neighbours & 21.7 \\
Social groups & 11.1 \\
Church & 7.9 \\
Elders & 28.0 \\
Total & 100 \\
\hline
\end{tabular}

\subsubsection{Choice of Indigenous Adaptation Strategy}

The survey results as illustrated in Table 4 found that households in Totope adopted different indigenous adaptation strategies to combat coastal flooding. Survey results showed that $19.7 \%$ of the respondents created barriers using sandbags to protect their homes and the portions of the community from being flooded during periods of heavy rains and storm surges. A total of $9.7 \%$ of the respondents stated that they raised their door steps with cement blocks to prevent floodwaters from entering their rooms whilst $10.7 \%$ of the respondents stated that they reinforced their windows using trampoline to prevent rainwaters from entering their rooms through the windows. Also $10.8 \%$ of the respondents stated that they created gutters around their homes to create a passage for floodwaters. In years where coastal flooding is severe, $12.6 \%$ of the respondents stated that they relocated temporally to Ada-Foah to stay with their relatives until the floodwater recedes.

A total of $19.7 \%$ of the household respondents pointed out that as part of household adaptations, traditional authorities in Totope performed rituals to pacify the sea god, as traditional leaders believe that the storm surges are a result of the anger of the sea god. The chief fisherman who participated in the focused group discussion stated that some of the indigenous adaptation strategies are becoming less effective in recent years due to the strong waves battering the shoreline of the community. Also $4.8 \%$ of the respondents stated that they raised the foundation of their building so as to get a higher platform before the building is put up.

Table 4. Indigenous adaptation strategies to combat coastal flooding.

\begin{tabular}{ll}
\hline Strategy & Percentage (\%) \\
\hline Filling compound & 5.9 \\
Creating sandbag barriers & 19.7 \\
Raised building platform & 4.8 \\
Raised doorsteps & 9.7 \\
Reinforced windows & 10.7 \\
Construction of drains & 6.0 \\
Temporal relocation & 12.6 \\
Creating pathway for water & 10.8 \\
Pouring libation to pacify god & 19.7 \\
\hline
\end{tabular}

The chief fisherman pointed out during the focus group discussion that some households use other indigenous adaptation strategies not mentioned in the responses in the questionnaire. The chief fisherman for instance pointed out that "households have created space in the roofs of their buildings where they pack their valuable items anytime the community is flooded".

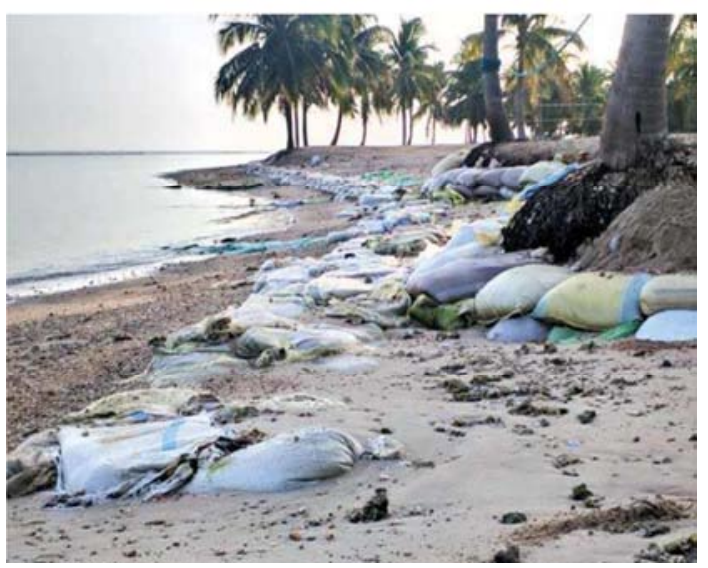

Figure 7. Sandbags used to block coastal flood waters.

An elder pointed out that as an adaptation strategy, some households use thatch to roof their houses instead of aluminium roofing sheets as the moisture brought by the sea waves lead to rapid corrosion of aluminium roofing sheets. It was also pointed out that to ensure clothes, mattresses and food supply remain dry, households build wooden platforms inside their rooms to keep these useful materials above the level of 
the flood water which enter their room. An elder also stated that "some households have pumping machines which they use to pump water out of their rooms and compound during floods". The chief fishermen opined that "fishermen during the periods of floods park their canoes offshore and swim inland with their catch since during the period there is no dry ground for them to park their boats".

An elder who was part of the focused group discussion pointed out that farmers in the Totope used to cultivate maize on a large scale but continuous flooding in the community has led to the inundation of their farmlands with sea water. This he stated has made the soil salty and reduced the ability of the soil to support the growth of maize. As a measure to deal with the problem, he opined that farmers are now cultivating shallot and pepper on a large scale as substitute crops. The elder further went on to say that some of the locals who can afford have acquired lands in nearby upland towns to continue with their farming activities.

All the 7 participants in the focused group discuss want urgent action from government to tackle the coastal flooding menace in the community as the problem has persisted for decades. The elders suggested that since the cost of building sea defense walls to provide a lasting solution to the problem is huge and the government of Ghana cannot provide funding for the project because of the current economic situation, government should relocate the Totope to one of the state lands north-east of the community.

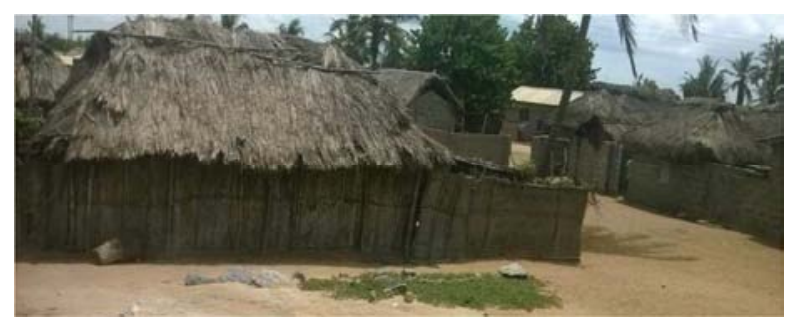

Figure 8. A thatch house in the study community.

The findings on the use of indigenous knowledge as an adaptation strategy in the study area is in line with the findings of other studies on the application of indigenous knowledge to disaster risk reduction. Studies in Kenya on the application of indigenous knowledge for disaster management showed that communities use indigenous knowledge of storm routes and wind patterns to design their disaster management activities long in advance before communities are hit by floods [27]. The findings are also in line with that of Aris et al (2015), who investigated the indigenous community responses and adaptation techniques to flood disaster in Jakarta. The study revealed that exposure to flood risk in on increase but however, varied indigenous adaptation strategies have been adopted by the people, which include raising the housing level, building small dykes to prevent water from entering the settlement and building terraced housing (10).

\subsubsection{Challenges Facing Choice of Adaptation Strategy}

The study sought to find out the challenges respondents encounter using their choice of adaptation strategy. The question allowed multiple responses so that households could cite all the challenges that inhibit their choice of adaptation strategy. The results showed that all the fiftythree (53) respondents unanimously agree there is lack of support from local and central government for their adaptation strategies. All fifty-three (53) respondents unanimously agree that they lack the financial resources to carry out their choice of adaptation strategy whilst nineteen (19) respondents lamented that the strategies they adopted are less effective during periods when the storm surge is strong, as their sandbag barriers are totally destroyed by the strong waves.

\subsection{Conclusion}

Totope, is exposed to coastal flooding because of its low lying elevation. To combat the dangers posed by flooding in the community, the locals have adopted indigenous strategies to deal with the flooding menace. The people of Totope adopted measures including filling their compound with sand to raise the elevation of the land; creating sandbags barriers to block flood water from entering their compounds; raising the foundation of buildings during construction; reinforcing windows with trampoline to prevent water from entering the room; construction of drains to allow passage of flood water; temporal relocation to other communities until the flood waters recede. The study found out that indigenous knowledge informed adaptation strategies suffer from lack of resources to carry out adaptation strategies. The community leaders want urgent action by government to deal with the coastal flooding menace in the community as some of their adaptation strategies are continuously being rendered less effective as a result of strong waves hitting the coast in recent years. The respondents believe that a long lasting solution to the coastal flooding menace in the community is a permanent relocation of the community to inland areas of the Ada East district since the construction of a sea defense wall requires huge capital commitment which will be difficult to meet anytime soon given Ghana's current economic situation.

\section{References}

[1] Addo, K. A. (2015). Monitoring sea level rise-induced hazards along the coast of Accra in Ghana. Nat. Hazards, 78 (2), 1293-1307.

[2] Aerts J. C. J. H., Botzen W. J., Clarke K. C., Cutter S. L, Hall J. W., Merz B., Michael-Kerjan E., Mysiak J., Surminski S., \& Kunreuther H. (2018). Integrating human behaviour dynamics into flood disaster risk assessment. Nat Clim Change 8: 193199.

[3] Agrawal, A. (1995a). Dismantling the Divide between Indigenous and scientific Knowledge. In Development and Change 26, pp. 413-439.

[4] Agrawal, A. (1995b). Indigenous and Scientific Knowledge: Some Critical Comments. In Indigenous Knowledge and Development Monitor (IKDM) 3 (3), 3-6. 
[5] Ajani, N. E., Mgbenka, N. R., \& Okeke, N. M. (2013). Use of Indigenous Knowledge as a Strategy for Climate Change Adaptation among Farmers in sub-Saharan Africa: Implications for Policy. In Journal of Agricultural Extension, Economics and Sociology 2 (1), 23-40.

[6] Antweiler, C. (1998). Local Knowledge and Local Knowing an Anthropological Analysis of Contested 'Cultural Products' in the Context of Development. In Anthropos 93, 469-494.

[7] Appeaning Addo, K., Lloyd, L., Amisigo, B. \& Ofori-Danson, P. K. (2011). 'Impacts of coastal inundation due to climate change in a cluster of urban coastal communities in Ghana, West Africa', Remote Sensing 3 (5), 2029-2050.

[8] Appeaning Addo, K. (2013). 'Shoreline morphological changes and the human factor: Case study of Accra Ghana', Journal of Coastal Conservation and Management, 17 (1), 85-91.

[9] Appeaning Addo, K. (2013). Assessing Coastal Vulnerability Index to Climate Change: the Case of Accra - Ghana'. Proceedings 12th International Coastal Symposium (Plymouth, England), Journal of Coastal Research, Special Issue No. 65, pp. 1892-1897, ISSN 0749-0208.

[10] Aris M. N., Sekaranom A. B., \& Ward P. (2015). Community responses and adaptation strategiestoward flood hazard in Jakarta, Indonesia. Natural hazards 75, (2), 1127-1144.

[11] Arns, A., Dangendorf, S., Jensen, J., Talke, S., Bender, J., \& Pattiaratchi, C. (2017). Sea-level rise induced amplification of coastal protection design heights. Nat. Sci. Rep. 7: 40171. doi: 10.1038/srep 40171

[12] Barnett J., Graham S., Mortreux C., Fincher R., Waters E., \& Hurlimann A. (2014). A local coastal adaptation pathway. Nat Clim Change doi: 10.1038/nclimate2383.

[13] Church J., Clark P., Cazenave A., Gregory J., Jevrejeva S., Merrifield M, Milne G., Nerem R., Nunn P., Payne A., Pfeffer W., Stammer D., \& Unnikrishnan A. S. (2013.) Sea Level Change, pages 1137-1216. Climate Change 2013: The Physical Science Basis. Contribution of Working Group I to the Fifth Assessment Report of the Intergovernmental Panel on Climate Change. Cambridge University Press, Cambridge, United Kingdom and New York, NY, USA.

[14] Codjoe, S. N. A., Owusu, G., \& Burkett, V. (2014). Perception, experience, and indigenousknowledge of climate change and variability: The case of Accra, a Sub-Saharan African city. Regional Environmental Change, 1-15.

[15] Di Baldassarre, G., Montanari, A., Lins, H., Koutsoyiannis, D. Brandimarte, L., \& Blöschl, G. (2010). Flood fatalities in Africa: From diagnosis to mitigation. Geophysical Research Letters, 37 (22), L22402.

[16] Emanuel K. A. (2013). Downscaling CMIP5 climate models shows increased tropical cyclone activity over the 21 st century. PNAS 110 (30): 12219-12224.

[17] Füssel, H. M. (2007). Adaptation planning for climate change: concepts, assessment approaches, and key lessons. Sustainability Science 2: 265-275.

[18] Hiwasaki, L., Luna E., \& Marçal, J. A. (2015). Local and indigenous knowledge on climate-related hazards of coastal and small island communities in Southeast Asia. Clim. Change, 128 (1-2), 35-56.

[19] Ghana Statistical Service (2012). '2010 Population and
Housing Census: Summary report of Results'. Accra: Ghana Statistical Service.

[20] Green, D., \& Raygorodetsky, G. (2010). Indigenous Knowledge of a Changing Climate. In Climate Change'. 100 (2010), 239-242.

[21] Hiwasaki, L., E. Luna, Syamsidik, \& Shawd R. (2014). Process for integrating local and indigenous knowledge with science for hydro-meteorological disaster risk reduction and climate change adaptation in coastal and small island communities. International Journal of Disaster Risk Reduction 10: 15-27.

[22] IPCC (2019). "Summary for policymakers," in IPCC Special Report on theOcean and Cryosphere in a Changing Climate, eds H.-O. Pörtner, D. Roberts, V. Masson-Delmotte, P. Zhai, M. Tignor, E. Poloczanska, et al. (Geneva: IPCC).

[23] IPCC (2014). Summary for policymakers. In Climate Change 2014: Impacts, Adaptation and Vulnerability. Part A: Global and Sectoral Aspects. Contribution of Working Group II to the Fifth Assessment Report of the Intergovernmental Panel on Climate Change [eds CB Field et al.]. Cambridge University Press, Cambridge, UK, and New York, NY, USA, 2014, 1-32.

[24] IPCC (2013). Summary for Policymakers. In: Climate Change 2013: The Physical Science Basis. Contribution of Working Group I to the Fifth Assessment Report of the Intergovernmental Panel on Climate Change [eds. TF Stocker et al.]. Cambridge University Press, Cambridge, United Kingdom and New York, NY, USA.

[25] Jevrejeva S., Jackson L. P., Riva RE, Grinsted A., \& Moore J. C. (2016). Coastal sea level rise with warming above 2 C. Proceedings of the National Academy of Sciences, 113 (47), 13342-13347.

[26] Jabulani, S. (2007). 'The challenges faced by African libraries information centres in documenting and preserving indigenous knowledge'. IFLA Journal 33 (2), 117-123.

[27] Kamara J. (2008). Indigenous Knowledge in Natural Disaster Reduction in Africa. Nairobi: UNEP.

[28] Kelman, I., Mercer, J., \& Gaillard, J. C. (2012). 'Indigenous knowledge and disaster risk reduction', Geography 97 (1), 12-21.

[29] Lawrence J, Bell R, Blacket P., Stephens S., Allan S. (2018). National guidance for adapting to coastal hazards and sealevel rise: Anticipating change, when and how to change pathway. Environ Sci Policy 82: 100-107.

[30] Lin-Ye, J.; García-León, M., Gracia, V., Sánchez-Arcilla, A. (2016). A multivariate statistical model of extreme events: An application to the Catalan Coast. Coast. Eng., 117, 138-156.

[31] McApline S. A., Porter J. R. (2018). Estimating Recent Local Impacts of Sea-Level Rise on Current Real- Estate Losses: A Housing Market Case Study in Miami-Dade, Florida. Population Research and Policy Review doi: 10.1007/s11113018-9473-5.

[32] Mercer J., Kelman I., Alfthan B., \& Kurvits T. (2012). Ecosystem-based adaptation to climate change in Caribbean Small Island developing states: integrating local and external knowledge. Sustainability Science 4: 1908-1932.

[33] Munich Reinsurance Company (2008). Natural catastrophes 2007: Analyses, assessment positions. Munich: Munich Reinsurance Company. 
[34] Mutasa, M., (2015). 'Knowledge apartheid in disaster management discourse: Is marrying indigenous and scientific knowledge the missing link?' Jamba: Journal of Disaster Risk Studies 7 (1), Art. \#150, 10.

[35] Neumann, B., Vafeidis, A. T., Zimmermann, J., \& Nicholls, R. J. (2015). Future coastal population growth and exposure to sea-level rise and coastal flooding-a global assessment. PLoS One 10: e0118571. doi: 10.1371/journal.pone.0118571.

[36] Mwaura, P. (2008). Indigenous knowledge in disaster management in Africa. United Nations Environment Programme, Nairobi.

[37] Newsham, A. J., \& Thomas, D. S. G. (2011). Knowing, farming and climate change adaptationin North-Central Namibia. Global Environmental Change, 21, 761-770.

[38] Nicholls, R. J. (2004). Coastal flooding andwetland loss in the 21st century: changes under the SRES climate and socioeconomic scenarios. Glob. Environ. Chang. 14, 69-86.

[39] Nicholls, R. J., \& Cazenave A. (2010). Sea-level rise and its impact on coastal zones. Science, 328 (5985), 1517-1520.

[40] Nicholls R. J., Townend I. H, Bardbury A. P, Ramsbottom D., \& Day S. A. (2013). Planning for long term coastal change: Experiences from England and Wales. Ocean Eng. Doi: 10.1016/j.oceaneng.2013.01.025.

[41] Nicholls RJ, Hinkel J, Lincke D., \& van der Pol T. (2019). Global Investment Costs for Coastal Defense through the 21st Century. The World Bank, doi: 10.1596/1813-9450-8745.

[42] Nyong, A., Adesina, F., \& Elasha, B. O. (2007). The value of Indigenous knowledge in climate change mitigation and adaptation strategies in the African Sahel-Mitigation and Adaptation Strategies. Global Change, 12, 787-797.

[43] Sakijege, T., Lupala, J., \& Sheuya, S. (2012). Flooding, flood risks and coping strategies in urban informal residential areas:
The case of Keko Machungwa, Dares Salaam, Tanzania. Jamba: Journal of Disaster Risk Studies 4 (1), Art. \#46, 10 pages. http://dx.doi.org/10.4102/jamba.v4i1.46 [Accessed 9/05/2013].

[44] Seneviratne, S. I. N., Nicholls, D., Easterling, C. M., Goodess, S., Kanae, J., Kossin, S., \& Zhang, X. (2012). Changes in climate extremes and their impacts on the natural physical environment. In: Field, C. B. V., Barros, T. F., Stocker, D., Qin, D. J., Dokken, K. L. \& Midgley, P. M. (Eds.), Managing the risks of extreme events and disasters to advance climate change adaptation. A special report of working groups I and II of the Intergovernmental Panel on Climate Change (IPCC). Cambridge \& New York, NY: Cambridge University.

[45] Sweet WV, Dusek G, Obeysekera J, \& Marra J. J. (2018). Patterns and Projections of High Tide Flooding Along the U.S. Coastline using a Common Impact Threshold, National Oceanic and Atmospheric Administration, Silver Spring, MD.

[46] Tschakert, P., Sagoe R., Ofori-Darko, G., \& Codjoe, S. N. (2010). Floods in the Sahel: An analysis of anomalies, memory and anticipatory learning. Climatic Change, 103 (3-4), 471-502.

[47] Vousdoukas MI, Mentashi L, Evangelos Voukouvalas, Verlaan M, Jevrejeva S., Jackson L. P, \& Feyen L. (2018). Global probabilistic projections of extreme sea levels show intensification of coastal flood hazard. Nat Commun 9: 2360.

[48] Vousdoukas MI, Voukouvalas E, Annunziato A, Giardino A., \& Feyen L. (2016). Projections of extreme storm surge levels along Europe. Clim Dyn 47 (9-10): 3171-3190.

[49] Wadey, M., Brown S., Nicholls, R. J., \& Haigh I. (2017). Coastal flooding in the Maldives: an assessment of historic events and their implications. Nat. Hazards, 89 (1), 131-159.

[50] Woodroffe, C. D., \& Murray-Wallace, C. V. (2012). Sea-level rise and coastal change: the past as a guide to the future. Quaternary Science Reviews, 54, 4-11. 